ZOOLOGIA 32(5): 371-379, October 2015

http://dx.doi.org/10.1590/S1984-46702015000500006

\title{
Cytogenetics and DNA barcoding of the Round-eared bats, Tonatia (Chiroptera: Phyllostomidae): a new karyotype for Tonatia bidens
}

\author{
Jaqueline R. Tavares', Tatiane P. de Sousa', Joaquim M. da Silva², \\ Paulo C. Venere $^{3} \&$ Karina de C. Faria ${ }^{2, *}$
}

\begin{abstract}
${ }^{1}$ Programa de Pós-graduação em Ecologia e Conservação, Universidade do Estado de Mato Grosso. Avenida Prof. Dr. Renato Figueiro Varella, 78690-000 Nova Xavantina, MT, Brazil.

${ }^{2}$ Faculdade de Ciências Agrárias, Biológicas e Sociais Aplicadas, Universidade do Estado de Mato Grosso. Avenida Prof. Dr. Renato Figueiro Varella, 78690-000 Nova Xavantina, MT, Brazil.

${ }^{3}$ Programa de Pós-graduação em Ecologia e Conservação da Biodiversidade, Instituto de Biociências, Universidade Federal de Mato Grosso. 78060-900 Cuiabá, MT, Brazil.

*Corresponding author. E-mail: karinafaria@unemat.br
\end{abstract}

\begin{abstract}
There are two species of Neotropical Round-eared bats, Tonatia bidens Spix, 1823 and Tonatia saurophila Koopman \& Williams, 1951, which present highly similar morphological characteristics that can lead to errors of identification. Specimens originally identified as $T$. bidens have recently been reclassified as $T$. saurophila, and the only karyotype documented previously for these species was $2 \mathrm{n}=16, \mathrm{FN}=20$. In the present study, specimens of Tonatia collected in the municipality of Barra do Garças, in the Brazilian state of Mato Grosso, were analyzed morphologically, using conventional cytogenetic techniques (C-banding, $\mathrm{Ag}-\mathrm{NOR}$, and $\mathrm{CMA}_{3}$ ), and through sequences of the mitochondrial cytochrome c oxidase subunit I (COI) gene. In the specimens morphologically identified as T. bidens, the diploid number $(2 n)$ was 26 , and the fundamental number (FN), 38, while in $T$. saurophila, $2 n=16$ and $F N=20$, which is the karyotype also described previously for $T$. bidens. The dendograms obtained with sequences of the COI marker resulted in the formation of two distinct groups between T. bidens and T. saurophila, consistent with the two species, with a high sequence divergence value (14.22\%). Distinct clades were also observed between T. bidens and the other phyllostomines analyzed in this study, with T. bidens also close to Phyllostomus hastatus (14.18\% of sequence divergence).
\end{abstract}

KEY WORDS. Chromosomes; COI gene; karyotypes; Phyllostominae; taxonomy.

The Phyllostomidae is endemic to the New World and one of the most morphologically diverse chiropteran family, with 203 known species arranged in 60 genera (SOLARI \& MarTinEz-Arias 2014). The exact number of subfamilies remains unclear, with between seven and 11 according to the phylogenetic approach adopted. The molecular evidence suggests that some subfamilies, such as the Phyllostominae, are paraphyletic, a classification supported by the chromosomal data (BAKER et al. 2003, Pieczarka et al. 2013, Ribas et al. 2015). However, the morphological evidence supports the classification in seven subfamilies, which includes a number of phyllostomine taxa that are not supported by the molecular evidence (WETTERER et al. 2000, Simmons 2005).

BAKER et al. (2003) arranged the Phyllostominae in three tribes - Macrophyllini, which includes Trachops Gray, 1827and Macrophyllum Gray 1838; Phyllostomini composed by Tonatia Gray, 1847, Lophostoma d'Orbigny, 1836, Mimon Gray 1847, Phyllostomus Lacépède, 1799; and Phylloderma Peters, 1865, and Vampyrini, with two genera, Chrotopterus Peters, 1865 and
Vampyrum Rafinesque, 1815. Tonatia originally included the species now assigned to Lophostoma, but is now composed of only two species, Tonatia bidens Spix, 1823 and Tonatia saurophila Koopman \& Williams, 1951. This alteration was proposed by LEe-JR et al. (2002) based on sequences of mitochondrial DNA, which revealed that T. bidens and T. saurophila formed a well-defined clade clearly separated from the other five species included originally in the genus, which did not correspond to a monophyletic group.

The type locality of the Greater round-eared bat, Tonatia bidens, is close to the São Francisco River in the Brazilian state of Bahia (Williams et al. 1995). The species is found throughout southern and central Brazil, ranging west and south into Bolivia, Paraguay, and northern Argentina (WiLliams et al. 1995, PACA et al. 2012, Reis et al. 2013). The type locality of the Stripeheaded round-eared bat, T. saurophila, is Wallingford Roadside Cave in Balaclava, St. Elizabeth Parish, Jamaica, although the species is known from this site only from fossils (Williams et al. 1995). This species ranges from southern Mexico (Chiapas)

2015 | Sociedade Brasileira de Zoologia | www.sbzoologia.org.br | www.scielo.br/zool All content of the journal, except where identified, is licensed under a Creative Commons attribution-type BY. 
through Belize, Colombia, Venezuela, Trinidad, the Guianas, Surinam, Ecuador, Peru, Bolivia, and Brazil, as far south as Argentina (Barquez \& Diaz 2001, Clarke \& Downie 2001, Simmons 2005, McDonough et al. 2011, SaAvedra-Rodríguez \& Rojas-Díaz 2011). In Brazil, T. saurophila is found predominantly in the north, with a limited distribution in the central and southern parts of the country (ReIs et al. 2013).

Tonatia bidens and T. saurophila present highly similar morphological characteristics, which may lead to the erroneous identification of species. Williams et al. (1995) recognized specimens originally identified as T. bidens to be in fact $T$. saurophila. These authors emphasized the light-colored stripe on the top of the head of T. bidens as the most useful diagnostic feature for the differentiation of the two species. In addition to these traits, a number of other characters are also useful for diagnosis, including measurements of the post orbital constriction, the secondary process on the mastoid, and the gap between the cingula of the lower canines.

The cytological data available on Tonatia refer to the karyotype of $T$. bidens as having a diploid number (2n) of 16 and a fundamental number (FN) of 20 (BAKER 1970, BAKER \& Hsu 1970, Patton \& Baker 1978, Baker \& Bickham 1980, Santos et al. 2002). However, nearly all these specimens were recognized as T. saurophila following the review of WiLLIAMs et al. (1995).

In recent years, a partial sequence of the mitochondrial cytochrome c oxidase subunit I (COI) gene has been used as a DNA barcode for the identification of species (HEBERT et al. 2003). While studies of COI in bats are incipient in general, the gene has been sequenced in more than 160 Neotropical species (Clare et al. 2007, 2011, Nesi et al. 2011, HernandezDA'vila et al. 2012).

In the present study, we diagnosed the karyotypes of specimens of T. bidens and T. saurophila captured in the Cerrado savanna of central Brazil, and used morphometric and COI sequences data to assess the identity of the species analyzed.

\section{MATERIAL AND METHODS}

Two female specimens of T. bidens and one female $T$. saurophila were collected from natural populations in the municipality of Barra do Garças, in eastern Mato Grosso, Brazil. The T. bidens specimens were collected in the Serra Azul State Park, a 11,000 ha area of Cerrado savanna, with diverse habitat types. One of the specimens was captured in well-preserved gallery forest neighboring an abandoned pasture, at an altitude of $533 \mathrm{~m}\left(15^{\circ} 50^{\prime} 17.5^{\prime \prime} \mathrm{S}, 52^{\circ} 14^{\prime} 56.0^{\prime \prime} \mathrm{W}\right)$. The second specimen was captured in an area of scrubby savanna, surrounded by more well-preserved vegetation, at an altitude of $728 \mathrm{~m}\left(15^{\circ} 49^{\prime} 36.2^{\prime \prime} \mathrm{S}\right.$, $\left.52^{\circ} 13^{\prime} 50.1^{\prime \prime} \mathrm{W}\right)$. The specimen of $T$. saurophila was collected from a gallery forest on a private property surrounded by well-preserved vegetation $\left(15^{\circ} 20^{\prime} 36.6^{\prime \prime} \mathrm{S}, 52^{\circ} 12^{\prime} 59.0^{\prime \prime} \mathrm{W}\right)$.

The bats were captured in $9 \times 3 \mathrm{~m}$ mist-nets, and specimen collection was authorized by the Brazilian federal environ- ment institute (IBAMA) through special license IBAMA-SISBIO \#18276-1. The specimens were initially identified based on the specialized literature (VizotTo \& TADDEI 1973, Gardner 2007, Reis et al. 2013) and the identifications were confirmed by Dr. Marlon Zortéa from the Animal Biodiversity Laboratory of the Universidade Federal de Goiás at Jataí, Goiás, Brazil. External and cranial measurements were taken following the protocol of VizotTo \& TADDEI (1973) with a manual caliper (0.05 mm precision), and presented in $\mathrm{mm}$. Once processed, the specimens were deposited as vouchers in the scientific collection of the Genetics Laboratory of Universidade do Estado de Mato Grosso (UNEMAT) at Nova Xavantina, under catalog numbers RM 338 and RM 356 (T. bidens), and RM 354 (T. saurophila).

Samples for cytogenetic analyses were extracted directly from the bone marrow of T. bidens e T. saurophila using an approach modified from Morielle-Versute et al. (1996). Chromosome morphology was observed through conventional Giemsa staining (GUERRA 1988), C-banding was based on the procedure described by SumNer (1973), and Ag-NOR staining followed Varella-Garcia \& TADDEI (1989).

Base-specific fluorochrome $\mathrm{CMA}_{3}$ staining adapted from SCHWEIzer (1980) was used to highlight the regions rich in C and $\mathrm{G}$. The chromosomes were measured and classified according to the position of the centromere, with four classes - metacentric, submetacentric, subtelocentric, and acrocentric, following LEVAN et al. (1964). An Olympus BX51 microscope was used to acquire the images and the karyotypes were mounted in Adobe Photoshop 7.0.

Samples of DNA were obtained from tissue fragments extracted from specimens RM 338 (T. bidens) and RM 354 (T. saurophila), as well as those of other phyllostomines collected in the Cerrado of Mato Grosso (Lophostoma silvicolum d'Orbigny, 1836: specimens RM 95, RM 105, RM 106 and RM 160 and Phyllostomus discolor Wagner, 1843: specimens RM 100, RM 122 and RM 245). The DNA was extracted following the protocol of Aljanabi \& Martinez (1997) and the COI primers FishF $_{2}$ and FishR ${ }_{2}$ (WARD et al. 2005) were used to amplify the COI gene. The PCR reaction contained a final volume of 12.5 $\mu \mathrm{l}$, including $9.08 \mu \mathrm{l}$ of autoclaved milli-Q water, $1.25 \mu \mathrm{l}$ of 10 $x$ PCR buffer, $0.375 \mu \mathrm{l}$ of $\mathrm{MgCl}_{2}(50 \mathrm{mM}), 0.25 \mu \mathrm{l}$ of each primer $(10 \mu \mathrm{M}), 0.20 \mu \mathrm{l}$ of $\mathrm{dNTP}(2.5 \mathrm{mM}), 0.10 \mu \mathrm{l}$ of Taq polymerase $(5 \mathrm{U} / \mu \mathrm{l})$, and $1.0 \mu \mathrm{l}$ of genomic DNA $(10 \mathrm{ng} / \mu \mathrm{l})$. The reactions were conducted in a graded Eppendorf thermocycler. The cycle consisted of an initial step of $5 \mathrm{~min}$ at $94^{\circ} \mathrm{C}$, followed by 30 cycles of $45 \mathrm{~s}$ at $94^{\circ} \mathrm{C}, 1 \mathrm{~min}$ at $50^{\circ} \mathrm{C}$, and $1 \mathrm{~min}$ at $72^{\circ} \mathrm{C}$, and a final extension of $5 \mathrm{~min}$ at $72^{\circ} \mathrm{C}$. The PCR products were run in $1.5 \%$ agarose gel solubilized in $0.5 \mathrm{x}$ TBE buffer and visualized under ultraviolet light. The PCR product of the COI gene was sequenced by a specialized company using the Sanger technique in an ABI 3500 Genetic Analyzer. The sequences were deposited in the National Center for Biotechnology Information (GenBank, http://www.ncbi.nlm.nih.gov) under the numbers KR921585 to KR921593. 
To improve our data, sequences of Desmodus rotundus (E. Geoffroy, 1810) and Diphylla ecaudata Spix, 1823, from GenBank, were added to the analyses as the outgroup, as well as 30 other specimens representing 10 genera of Phyllostominae in the ingroup: T. saurophila, Lophostoma schulzi (Genoways \& Williams, 1980), Lophostoma carrikeri (J.A. Allen, 1910), Lophostoma brasiliense Peters, 1867, Lophostoma evotis (Davis \& Carter, 1978), Chrotopterus auritus (Peters, 1856), Micronycteris nicefori (Sanborn, 1949), Macrophyllum macrophyllum (Schinz,1821), Mimon crenulatum (E. Geoffroy, 1803), Phylloderma stenops Peters, 1865, Phyllostomus hastatus (Pallas, 1767), Trachops cirrhosus (Spix, 1823), and Vampyrum spectrum (Linnaeus, 1758).

The sequences were added using Blastn (default parameters) by scoring $\geqslant 90 \%$ identities with our sequences, aligned using the webPRANK alignment server with default settings (LÖYTYNOJA \& GOLDMAN 2005) and edited manually in MEGA 6.0 (TAMura et al. 2013). MEGA6 was used to identify the best-fitting model of nucleotide substitution using the second-order Akaike Information Criteria (AICc) (AKAIKe 1974, SugIURA 1978). Branches corresponding to partitions reproduced in less than $50 \%$ bootstrap replicates were collapsed (FeLSENSTEIN 1985). The evolutionary history was inferred by using the Neighbor-Joining (NJ) and Maximum lilelihood (ML) methods. For the NJ, the evolutionary distances were computed using Tamura-Nei method (TAMURA \& Nei 1993) and the rate variation among sites was modeled with a gamma distribution. For the ML, the evolutionary distances were computed using the Hasegawa-KishinoYano model (HASEgAWA et al. 1985), a discrete Gamma distribution was used to model evolutionary rate differences among sites (5 categories) and the rate variation model allowed for some sites to be evolutionarily invariable. For both $\mathrm{NJ}$ and ML analyses, the codon positions included were $1^{\text {st }}+2^{\text {nd }}+3^{\text {rd }}+$ Non-coding. All ambiguous positions were removed for each sequence pair. There were a total of 591 positions in the final dataset. All evolutionary analyses were conducted in MEGA6.

\section{RESULTS}

The morphometric analyses revealed a high degree of similarity between the species in body size, with external and cranial dimensions typical of the respective species (Table 1). In addition to these measurements, which overlapped in the two species, qualitative diagnostic features were also evaluated for the differentiation of the specimens. The two species were distinguished by the following traits: (i) the presence of a white stripe on the top of the head of T. saurophila, which was absent from $T$. bidens, (ii) presence of a narrow opening between the lower canines and relatively narrow lower incisors in T. bidens, in contrast with a wider space and broader incisors in $T$. saurophila, (iii) presence of a broader post-orbital constriction in the cranium of $T$. bidens in comparison with T. saurophila, (iv) agglomeration in the second lower premolar, which is obscured by the cingula of the first and third premolars in T. bidens, whereas in T. saurophila, the second lower premolar is more robust and is not obscured by the neighboring premolars (Figs. 1-4).

Table 1. External and cranial measurements $(\mathrm{mm})$ of specimens of Tonatia bidens and T. saurophila captured in the Cerrado savanna of central Brazil.

\begin{tabular}{lccc}
\hline $\begin{array}{c}\text { Measurements } \\
(\mathrm{mm})\end{array}$ & $\begin{array}{c}\text { T. bidens } \\
\text { (RM 338) }\end{array}$ & $\begin{array}{c}\text { T. bidens } \\
\text { (RM 356) }\end{array}$ & $\begin{array}{c}\text { T. saurophila } \\
\text { (RM 354) }\end{array}$ \\
\hline Forearm & 56.0 & 53.5 & 59.1 \\
Greatest length of skull & 27.1 & 27.0 & 28.5 \\
Condylobasal length & 25.4 & 25.6 & 26.4 \\
Zygomatic breadth & 13.8 & 12.8 & 14.9 \\
Postorbital constriction breadth & 5.7 & 5.7 & 5.3 \\
Braincase breadth & 10.9 & 10.7 & 11.5 \\
Mastoid breadth & 13.0 & 12.8 & 13.4 \\
Maxillary toothrow length & 9.6 & 9.5 & 9.9 \\
Width across molars & 8.5 & 8.5 & 9.1 \\
Width across canines & 5.8 & 5.7 & 5.7 \\
Weight (g) & 30.0 & 27.0 & 37.0 \\
\hline
\end{tabular}

Tonatia bidens presented $2 \mathrm{n}=26$. The karyotype consisted of three pairs of metacentric chromosomes (6, 10 and 12), two submetacentric pairs (4 and 8$)$, three subtelocentric pairs (1, 9 and 11), and five acrocentric pairs (2, 3, 5, 7 and 13). Although it was not possible to identify the sexual chromosomes directly, the $\mathrm{FN}$ is probably equal to 38 due to the fact that most phyllostomids and phyllostomines present a conserved biarmed X (Patton \& Baker 1978, Ribas et al. 2015). A nucleolar organizer region (Ag-NOR) was identified in one pair of acrocentric chromosomes (pair 13), while the C-banding indicated the presence of regions of constitutive heterochromatin in the pericentromeric regions of all the chromosomes (Figs. 5-7).

The karyotype of $T$. saurophila was $2 \mathrm{n}=16$ and $\mathrm{FN}=20$. This set of autosomal chromosomes included one metacentric pair (1), two submetacentric pairs (5 and 6) and four acrocentric pairs $(2,3,4$ and 7$)$. The $\mathrm{X}$ chromosomes are the smallest submetacentric pair in the karyotype (PATTON \& BAKER 1978, RiBAs et al. 2015). The Ag-NORs were observed in the acrocentric pair 4 . The C-banding identified regions of constitutive heterochromatin in the centromeric regions of pairs 1, 2, 6 and $X$, and in the interstitial regions in pairs 3, 4 and 5 (Figs. 8-10).

The DNA barcode obtained here for T. bidens was the first of its kind for the species. The NJ and ML analyses produced different topologies; however, T. bidens and T. saurophila appear as sister taxa in both trees with a higher value bootstraps in the ML (71\%) (Figs. 11 and 12). The comparison of the sequence divergence values obtained for T. bidens and $T$. saurophila with those of other Phyllostominae from Mato Grosso and GenBank, indicated that they belong to two distinct species, and T. bidens is closer to T. saurophila (14.22\%) and to P. hastatus (14.18\%) (Table 2). 



Figures 1-4. (1) T. bidens (RM 338); (2) cranium (left), mandible (center) and lower dentition of (right) T. bidens: (a) broad post-orbital constriction, (b) narrow opening separating the lower canines, (c) narrow lower incisors, and d) agglomeration of the second lower premolar; (3) T. saurophila (RM 354), showing the distinct white stripe on the top of the head (arrow); (4) cranium (left), mandible (center) and lower dentition (right) of $T$. saurophila: (e) post-orbital constriction less evident, (f) lower canines separated by a relatively wide space, $(\mathrm{g})$ relatively broad lower incisors, and $(\mathrm{h})$ second lower premolar more robust and less agglomerated.



Figures 5-10. Representative karyotypes with Giemsa, Ag-NOR staining, C-banding and base-specific fluorochrome CMA ${ }_{3}$ staining of $T$. bidens (5-7) and T. saurophila (8-10). 


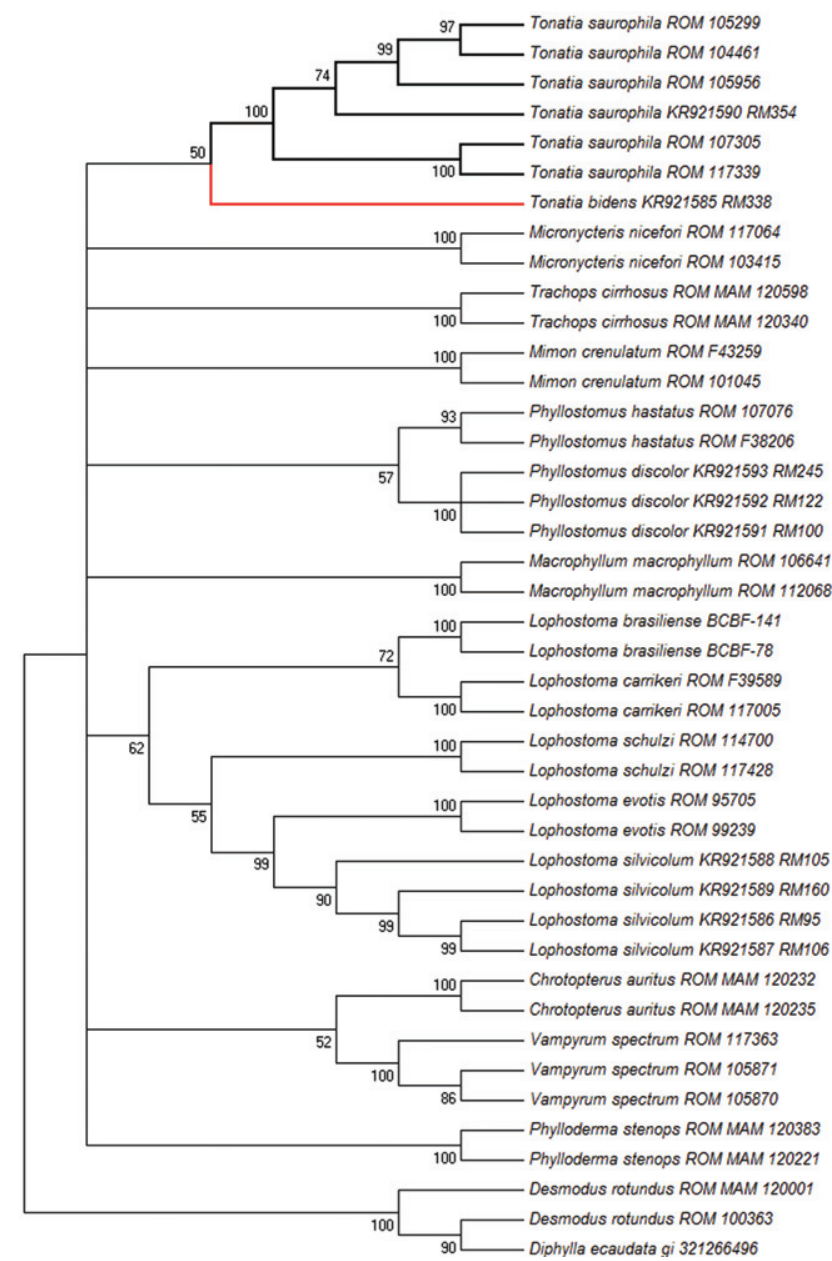

Figure 11. Neighbor-joining (NJ) dendogram describing relationships among genera of bats in Phyllostominae and calculated from COI sequence data (the species of Tonatia are highlighted). The best model for the evolutionary distance was computed using Tamura-Nei method. The sequences under the numbers KR921585 to KR921593 belong to specimens collected in the Cerrado of Mato Grosso.

\section{DISCUSSION}

Few data are available on Tonatia from the wild, and most authors have considered these bats to be rare (EsBérARD \& BERGALLO 2004). While a large number of inventories have been conducted in Brazil, records of this genus and cytogenetic data (SANTOS et al. 2002, Ribas et al. 2015) are scant. We considered the external morphological characteristics and cranial measurements presented by WiLLIams et al. (1995) for the identification of the specimens analyzed in the present study. Karyotyping indicated $2 \mathrm{n}=26$ and $\mathrm{FN}=38$ for T. bidens, and $2 \mathrm{n}=16$ and $\mathrm{FN}$ = 20 for T. saurophila. Previous studies (BAKER 1970, 1979, BAKER

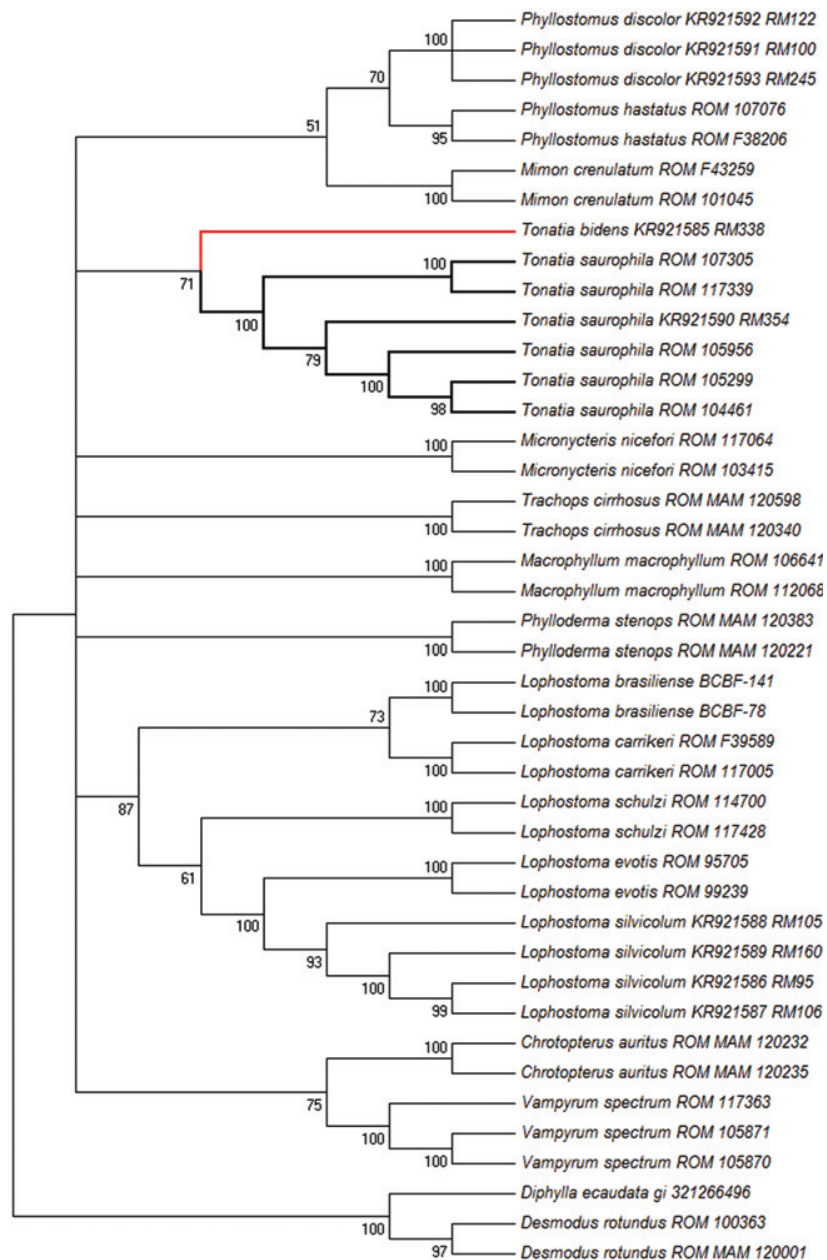

Figure 12. Maximum likelihood (ML) dendogram describing relationships among genera of bats in Phyllostominae and calculated from COI sequence data (the species of Tonatia are highlighted). The best model for the evolutionary distance was computed using the Hasegawa-Kishino-Yano model. The sequences under the numbers KR921585 to KR921593 belong to specimens collected in the Cerrado of Mato Grosso.

\& Hsu 1970, Gardner 1977, PatTon \& BaKer 1978, BaKer \& BickHam 1980, Honeycutt et al. 1980) assigned a karyotype of $2 \mathrm{n}=16$ $(\mathrm{FN}=20)$ to $T$. bidens, however, these were recognized as $T$. saurophila after the findings of Williams et al. (1995).

In chiropterans, chromosomal conservatism is so intense in some genera that different species may present the same chromosomal constitution, and even the same G-banding pattern (Baker 1970, Morielle-Versute et al. 1996, Faria \& MorielleVERSUTE 2006). In some genera, however, considerable variation is found in the diploid and fundamental numbers (VARELLAGarcia \& Taddei 1989, Silva et al. 2005). The marked diploid number variation found in the Tonatia species is not unique 


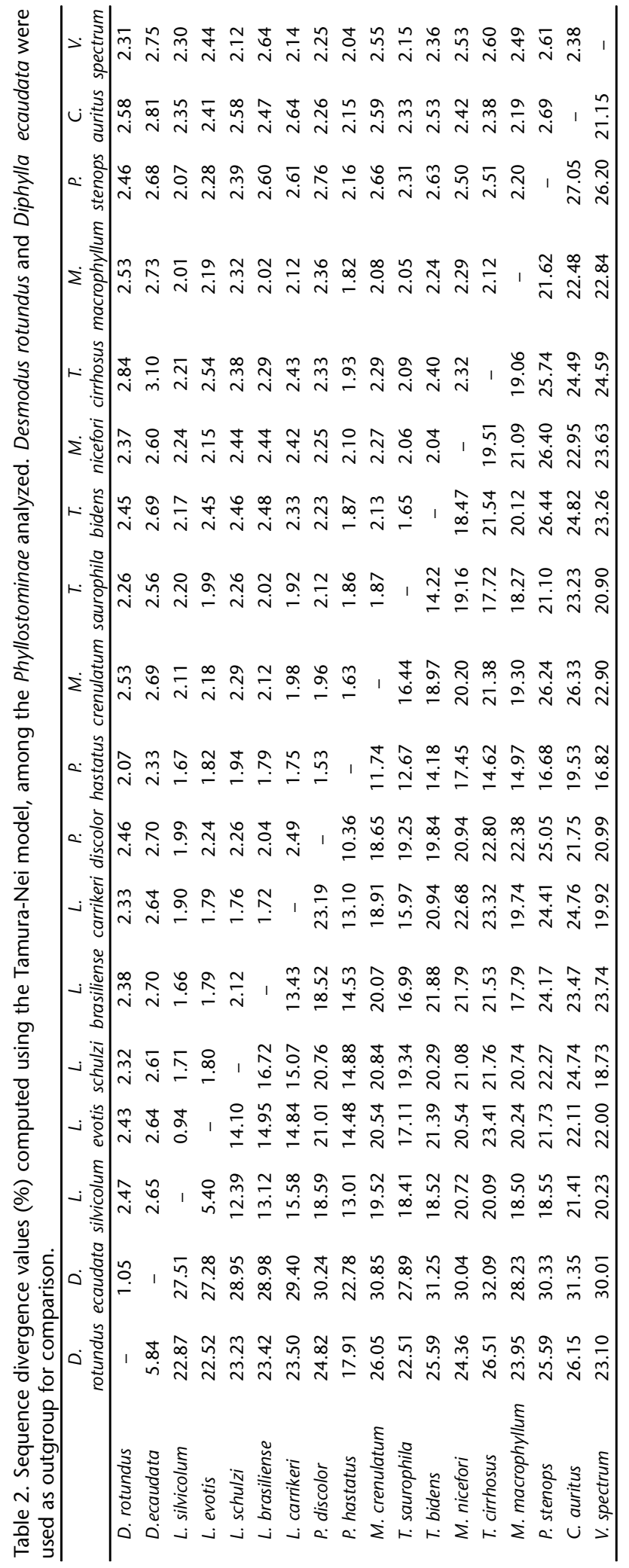

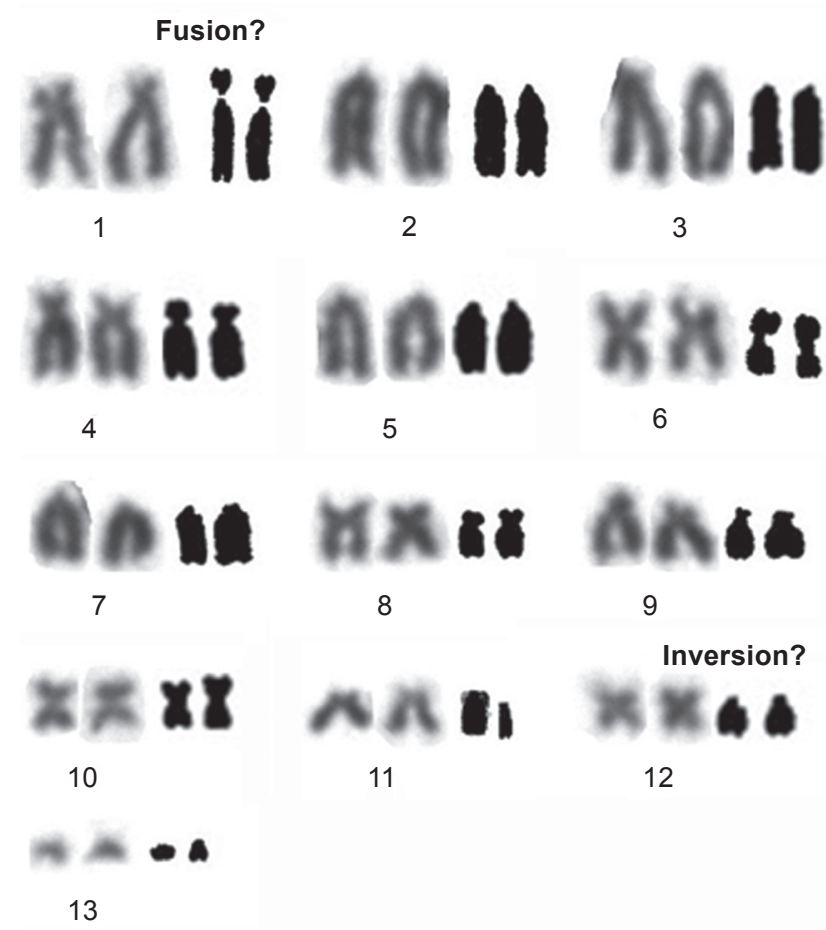

Figure 13. Chromosomal comparison between $T$. bidens collected in the Brazilian state of Mato Grosso (left) and L. schulzi (HonEYCUTT et al. 1980).

among congeners within Phyllostomidae. The number of chromosomes can vary from a single extra pair in different Mimon species to seven extra pairs in Micronycteris Gray, 1847 (BAKER \& Hsu 1970, Patton \& BaKer 1978, BaKer 1979, BaKer et al. 1981, Ribas et al. 2013).

The karyotype of $T$. bidens recorded in the present study not only contrasted considerably with that of $T$. saurophila, but also with those of most other bat species. A number of other species have a diploid number of 26 , although their chromosomal morphology is quite distinct, being reflected in different fundamental numbers (GARDNER 1977, BAKER 1967, BAKER \& Jordan 1970, BaKer et al. 1981, Varella-Garcia et al. 1989).

When compared to the karyotypes of the species of Lophostoma, which were previously considered to be members of Tonatia, $T$. saurophila $(2 \mathrm{n}=16, \mathrm{FN}=20)$ was considered to be the most divergent, and no interspecific homologies in the $G$ banding could be identified (PatTon \& BaKer 1978). Baker \& BiскнAм (1980) concluded that the karyotypic differences found in the Tonatia species were the result of a number of different rearrangements, which occurred primarily in the $2 \mathrm{n}=16$ karyotype, considered to be the most derived of all. However the karyotype of $T$. bidens presented here $(2 \mathrm{n}=26, \mathrm{FN}=38)$ is highly similar to that described for L. schulzi $(2 \mathrm{n}=28, \mathrm{FN}=36)$ (HoneycutT et al. 1980), which apparently differ by only a few chromosomal rearrangements (Fig. 13). 
The Ag-NORs of T. saurophila identified in the present study were found on the same pair of medium-sized acrocentric chromosomes (pair 4) identified in previous studies (SANTOS et al. 2002, Martins et al. 2010, Ribas et al. 2015). The Ag-NORs described here for the new karyotype of $T$. bidens were observed on the smallest pair of acrocentric chromosomes (pair 13). The constitutive heterochromatin found in the pericentromeric region of the chromosomes of T. bidens and in the pericentromeric and interstitial regions of some of the chromosomes of T. saurophila was consistent with the pattern observed in other studies of phyllostomine bats (Varella-Garcia et al. 1989, Morielle-Versute et al. 1996, Santos et al. 2001, Silva et al. 2005, BArros et al. 2009, Gomes et al. 2010).

In the DNA barcoding analyses, the T. saurophila specimen from the present study grouped decisively with those from GenBank, forming a distinct clade in relation to the T. bidens specimen, emphasizing the differentiation of the two species. Samples of a number of different species of phyllostomines were also included here for comparison, using Hoffmann et al. (2008) as the reference for the choice of the taxa. In this work, the authors performed independent Bayesian and maximum likelihood analyses with the complete cytochrome-b gene, 12S$16 \mathrm{~S}$ rRNA and RAG-2 sequences. The authors also confirmed the status of T. bidens and T. saurophila as sister taxa, albeit the ML phylogram obtained presented a higher resolution topology, with nodes most strongly supported by a bootstrap $\geqslant 80 \%$, higher than the value found in this study. In addition, genetic distance values obtained here do not allow us to state that the specimen $2 \mathrm{n}=26$ is indeed a Tonatia, since the values show $T$. bidens also close to $P$. hastatus.

Overall, although the specimens of Tonatia captured in the Cerrado savanna of Mato Grosso were highly similar in general morphology, they presented a number of diagnostic traits in external and cranial morphology, which allowed them to be distinguished systematically, based on the proposal of Williams et al. 1995, and identified as T. bidens (RM 338 and RM 356) and T. saurophila (RM 354). The constitution of the karyotype of $T$. bidens was also completely different from that of T. saurophila and most other phyllostomid species, providing an additional diagnostic parameter for the differentiation of the species. The fact that this karyotype $(2 \mathrm{n}=26, \mathrm{FN}=38)$ is closely similar to that of $L$. schulzi raised the possibility that the species found in the Cerrado of Mato Grosso may in fact be an undescribed form of Lophostoma or other Phyllostominae from western Brazil. In addition, values obtained in the molecular analyses (COI) indicate that T. bidens and T. saurophila are distinct species, phylogenetically related, but the genetic distance values do not provide enough support to state that they belong to the same genus. Thus, further analysis including other T. bidens individuals and sequences of other mitochondrial and nuclear genes may provide us more robust molecular information that will allow us to confirm the taxonomic status of the specimens identified as T. bidens.

\section{ACKNOWLEDGEMENTS}

The authors thank the Fundação de Amparo à Pesquisa do Estado de Mato Grosso, Conselho Nacional de Desenvolvimento Científico e Tecnológico and the Coordenação de Aperfeiçoamento de Pessoal de Nível Superior for financial support; Dr. Marlon Zórtea for assistance in identifying specimens; the biologists Sérgio Oliveira, Loana Souza and Hellen Silva for their help in fieldwork.

\section{LITERATURE CITED}

AKAIKE H (1974) A new look at the statistical model identification. IEEE Transactions on Automatic Control 19: 716-723.

ALJANABi SM, Martinez I (1997) Universal and rapid salt-extraction of high quality genomic DNA for PCR-based techniques. Nucleic Acids Res 25: 4692-4693. doi: 10.1093/nar/25.22.4692

BAKER RJ (1967) Karyotypes of bats of the family Phyllostomidae and their taxonomic implications. Southwestern Naturalist 12: 407-428.

BAKER RJ (1970) Karyotypic trends in bats, p. 65-97. In: WinsatT WA (Ed). Biology of bats. New York, Academic Press.

BAKER RJ (1979) Karyology, p. 107-155. In: BAKER RJ, JONES-JR JK, CARTER DC (Eds.). Biology of bats of the New World family Phyllostomatidae Part 3. Lubbock, Special publications of the Museum of Texas Tech University.

BAKER RJ, Hsu TC (1970) Further studies in the sex chromosome systems of American leaf-noased bats (Chiroptera: Phyllostomatidae). Cytogenetics 9: 131-138.

BAKER RJ, JoRdAn RG (1970) Chromosomal studies of some Neotropical bats of the families Emballonuridae, Noctilionidae, Natalidae, and Vespertilionidae. Caryologia 23: 595-604.

BAKER RJ, BICKHAM JW (1980) Karyotypic evolution in bats: evidence of extensive and conservative chromosomal evolution in closely related taxa. Systematic Zoology 29: 239-253.

Baker RJ, Genoways HH, Seyfarth PA (1981) Results of the Alcoa Foundation-Suriname Expeditions. VI: Additional Chromosomal Data for Bats (Mammalia, Chiroptera) from Suriname. Carnegie Museum of Natural History 50: 333-344.

Baker RJ, Hoofer SR, Porter CA, Van Den Bussche RA (2003) Diversification among new-world leaf-nosed bats: an evolutionary hypothesis and classification inferred from digenomic congruence of DNA sequence. Occasional Papers, Museum of Texas Tech University 230: 1-32.

BARQUeZ RM, Díaz MM (2001) Bats of the Argentine Yungas: a systematic and distributional analysis. Acta Zoologica Mexicana 82: 29-81.

Barros HMDr, Sotero-Caio CG, Santos N, Souza MJ (2009) Comparative cytogenetic analysis between Lonchorhina aurita and Trachops cirrhosus. (Chiroptera, Phyllostomidae). Genetics and Molecular Biology 32: 748-752. doi: 10.1590/ S1415-47572009005000095 
Clare EL, Lim BK, Engstrom MD, Eger JL, Hebert PDN (2007) DNA barcoding of Neotropical bats: species identification and discovery within Guyana. Molecular Ecology Notes 7: 184-190. doi: 10.1111/j.1471-8286.2006.01657.x

Clare EL, Lim BK, Fenton MB, Hebert PDN (2011) Neotropical Bats: Estimating Species Diversity with DNA Barcodes. PLoS One 6: e22648. doi: 10.1371/journal.pone.0022648

Clarke FM, Downie JR (2001) A bat (Chiroptera) survey of Mora rainforest in Trinidad's Victoria-Mayaro Forest Reserve. Biodiversity and Conservation 10: 725-736. doi: 10.1023/ A:1016617127925

Esbérard CEL, Bergallo HG (2004) Aspectos sobre a biologia de Tonatia bidens (Spix) no estado do Rio de Janeiro, sudeste do Brasil (Mammalia, Chiroptera, Phyllostomidae). Revista Brasileira de Zoologia 21(2): 253-259. doi: 10.1590/ S0101-81752004000200014

Faria KC, Morielle-Versute E (2006) Genetic relationships between Brazilian species of Molossidae and Phyllostomidae (Chiroptera, Mammalia). Genetica 126: 215-225. doi: 10.1007/s10709-005-1450-3

Felsenstein J (1985) Confidence limits on phylogenies: An approach using the bootstrap. Evolution 39: 783-791.

GARDNER AL (1977) Chromosomal variation in Vampyressa and a review of chromosomal evolution in the Phyllostomidae (Chiroptera). Systematic Biology 26: 300-318.

Gardner AL (2007) Mammals of South America: Marsupials, Xenarthrans, Shrews, and Bats. Chicago, University of Chicago Press, 690p.

Gomes AJB, Rodrigues LRR, Rissino JD, Nagamachi CY, Pieczarka JC (2010) Biogeographical karyotypic variation of Rhinophylla fischerae (Chiroptera: Phyllostomidae) suggests the occurrence of cryptic species. Comparative Cytogenetics 4: 79-85. doi: 10. 3897/compcytogen.v4il.24

GuERRA M (1988) Introdução à Citogenética Geral. Rio de Janeiro, Guanabara Koogan, 142p.

Hasegawa M, Kishino H, Yano T (1985) Dating the human-ape split by a molecular clock of mitochondrial DNA. Journal of Molecular Evolution 22: 160-174.

Hebert PDN, Cywinska A, Ball SB, WaARd JR (2003) Biological identifications through DNA barcodes. Proceedings of the Royal Society of London. Series B: Biological Sciences 270: 313-321. doi: 10.1098/rspb.2002.2218

Hernandez-Da'Vila A, Vargas JA, Martinez-Mendez N, Lim BK, Engstrom MD, Ortega J (2012) DNA barcoding and genetic diversity of phyllostomid bats from the Yucatan Peninsula with comparisons to Central America. Molecular Ecology Resources 12: 590-597. doi: 10.1111/j.1755-0998.2012.03125.x

Hoffmann FG, Hoofer SH, BaKer RJ (2008) Molecular dating of the diversification of Phyllostominae bats based on nuclear and mitochondrial DNA sequences. Molecular Phylogenetics and Evolution 49: 653-658. doi: 10.1016/j.ympev.2008.08.002

Honeycutt RL, BaKer RJ, Genoways HH (1980) Results of the Alcoa Foundation-Suriname Expeditions III. Chromosomal data for bats from Suriname (Mammalia: Chiroptera). Annals of the Carnegie Museum of Natural History 49: 237-250.

LeE-Jr TE, Hoofer SR, Bussche RAVD (2002) Molecular phylogenetics and taxonomic revision of the genus Tonatia (Chiroptera: Phyllostomidae). Journal of Mammalogy 83: 49-57. doi: 10.1644/1545-1542(2002)083<0049:MPATROÃ2.0.CO;2

Levan A, Fredga K, Sandberg AA (1964) Nomenclature for centromeric position on chromosomes. Hereditas 52: 201220. doi: 10.1111/j.1601-5223.1964.tb01953.x

LÖYTYNoJa A, Goldman N (2005) An algorithm for progressive multiple alignment of sequences with insertions. PNAS 102: 10557-10562. doi: 10.1073/pnas.0409137102

Martins C, Cabral-de-Mello DC, Valente GT, Mazzuchelli J, OliVEIRA SG (2010) Cytogenetic Mapping and Contribution to the Knowledge of Animal Genomes. Advances in Genetics Research 4: 1-81.

McDonough MM, Ferguson AW, Ammerman LK, Granja-Vizcaino C, Burneo SF, BaKer RJ (2011) Molecular verification of bat species Collected in Ecuador: results of a Country-wide survey. Museum of Texas Tech University 301: 1-28.

Morielle-Versute E, Varella-Garcia M, Taddei VA (1996) Karyotypic patterns of seven species of molossid bats (Molossidae, Chiroptera). Cytogenetics and Cell Genetics 72: 26-33. doi: 10.1159/000134154

Nesi N, Nakoune E, Cruad C, Hassanin A (2011) DNA barcoding of African fruit bats (Mammalia, Pteropodidae). The mitochondrial genome does not provide a reliable discrimination between Epomophorus gambianus and Micropteropus pusillus. Comptes Rendus Biologies 334: 544 554. doi: 10.1016/j.crvi.2011.05.003

Paca RC, Acosta LH, Aguanta FS (2012) Primer registro de Tonatia bidens (Spix, 1823) (Chiroptera: Phyllostomidae), en Bolívia. Chiroptera Neotropical 18: 1063-1066.

Patton JC, Baker RJ (1978) Chromosomal homology and evolution of Phyllostomatoid bats. Systematic Zoology 27: 449-462.

Pieczarka JC, Gomes AJB, Nagamachi CY, Rocha DCC, Rissino Jd, O'Brien PC, YANG F, Fergunson-Smith MA (2013) A phylogenetic analysis using multidirectional chromosome painting of three species (Uroderma magnirostrum,U. bilobatum and Artibeus obscurus) of subfamily Stenodermatinae (ChiropteraPhyllostomidae). Chromosome Research 21: 383-92. doi: 10.1007/s10577-013-9365-9

Reis NR, Fregonezi MN, Peracchi AL, Shibatta OA (2013) Morcegos do Brasil - Guia de Campo. Rio de Janeiro, Technical Books, 252p.

Ribas T, Rodrigues L, Nagamachi C, Gomes A, Rissino J, Benathar T, O’Brien P, Yang F, Ferguson-Smith M, Pieczarka J (2013) Two new cytotypes reinforce that Micronycteris hirsuta Peters, 1869 does not represent a monotypic taxon. BMC Genetics 14: 119. doi: 10.1186/1471-2156-14-119

Ribas T, Rodrigues L, Nagamachi C, Gomes A, Rissino J, O’Brien P, Yang F, Ferguson-Smith M, Pieczarka J (2015) Phylogenetic 
Reconstruction by Cross-Species Chromosome Painting and G-Banding in Four Species of Phyllostomini Tribe (Chiroptera, Phyllostomidae) in the Brazilian Amazon:An Independent Evidence for Monophyly. PLoS One 10(3): e0122845. doi: 10.1371/journal.pone.0122845

SaAvedra-Rodríguez CA, Rojas-Díaz V (2011) Chiroptera, midCalima River Basin, Pacific Slope of the Western Andes, Valle del Cauca, Colombia. CheckList 7: 166-172.

Santos N, Fagundes V, Yonenaga-Yassuda Y, Souza MJ (2001) Comparative karyology of Brazilian vampire bats Desmodus rotundus and Diphylla ecaudata (Phyllostomidae, Chiroptera): banding patterns, basespecific fluorochromes and FISH of ribosomal genes. Hereditas 134: 189-194. doi: 10.1111/j.1601-5223.2001.00189.x

Santos N, Fagundes V, Yonenaga-Yassuda Y, Souza MJ (2002) Localization of rRNA genes in Phyllostomidae bats reveals silent NORs in Artibeus cinereus. Hereditas 136: 137-143. doi: 10.1034/j.1601-5223.2002.1360208.x

SCHWEizer D (1980) Simultaneous fluorescent staining of R bands and specific heterochromatic regions (DA-DAPI bands) in human chromosomes. Cytogenetics and Cell Genetics 27: 190-193. doi: 10.1159/000131482

Silva AM, Marques-Aguiar SA, Barros RMS, Nagamachi Cy, Pieczarka JC (2005) Comparative cytogenetic analysis in the species Uroderma magnirostrum and U. bilobatum (cytotype $2 \mathrm{n}=42$ ) (Phyllostomidae, Stenodermatinae) in the Brazilian Amazon. Genetics and Molecular Biology 28: 248-253. doi: 10.1590/S1415-47572005000200012

Simmons NB (2005) Order Chiroptera, p. 312-529. In: WiLson DE, ReEder DM, Baltimore MD (Eds.). Mammal species of the world: a taxonomic and geographic reference. Baltimore, Johns Hopkins University Press, 3rd ed.

Solari S, Martínez-Arias V (2014) Cambios recientes en la sistemática y taxonomía de murciélagos Neotropicales (Mammalia: Chiroptera). Therya 5: 167-196. doi: 10.12933/ therya-14-180
SugruRA N (1978) Further analysis of the data by Akaike's information criterion and the finite corrections. Communications in Statistics - Theory and Methods 7: 13-26. doi: 10.1080/ 03610927808827599

Sumner AT (1973) A simple technique for demonstrating centromeric heterochromatin. Experimental Cell Research 75: 304-306.

Tamura K, Nei M (1993) Estimation of the number of nucleotide substitutions in the control region of mitochondrial DNA in humans and chimpanzees. Molecular Biology and Evolution 10: 512-526.

Tamura K, Stecher G, Peterson D, Filipski A, Kumar S (2013) MEGA6: molecular evolutionary genetics analysis versão 6.0. Biologia Molecular e Evolução 30: 2725-2729.

Varella-Garcia M, TAdDEI VA (1989) Citogenética de quirópteros: métodos e aplicações. Revista Brasileira de Zoologia 6(2): 297-323. doi: 10.1590/S0101-81751989000200015

Varella-Garcia M, Morielle-Versute E, Taddei VA (1989) A survey of cytogenetic data on Brazilian bats. Revista Brasileira Genética 12: 761-793.

Vizotto LD, TAdDei VA (1973) Chave para determinação de quirópteros brasileiros. Boletim de Ciências 1: 1-72.

Ward RD, Zemlak TS, InNes BH, Last PR, Hebert PDN (2005) DNA barcoding Australia's fish species. Philosophical Transactions of the Royal Society B: Biological Science 360: 1847-1857. doi: 10.1098/rstb.2005.1716

Wetterer AL, Rockman MV, Simmons NB (2000) Phylogeny of Phyllostomid bats (Mammalia: Chiroptera). Data from diverse morphological systems, sex chromosome, and restriction sites. Bulletin of the American Museu of Natural History 248: 1200. doi: 10.1206/0003-0090(2000)248<0001:POPBMC>2.0.CO;2

Williams SL, Willig MR, ReId FA (1995) Review of the Tonatia bidens complex (Mammalia: Chiroptera), with descriptions of two new subspecies. Journal of Mammalogy 76: 612626. doi: $10.2307 / 1382370$

Submitted: 25 February 2015

Received in revised form: 5 August 2015

Accepted: 21 September 2015

Editorial responsibility: Maria Wilhelmina Pil 